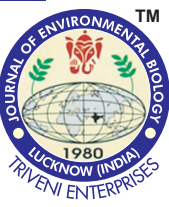

\title{
Rapid detection of bacteria, Enterococcus faecalis, in airborne particles of Hermosillo, Sonora, México
}

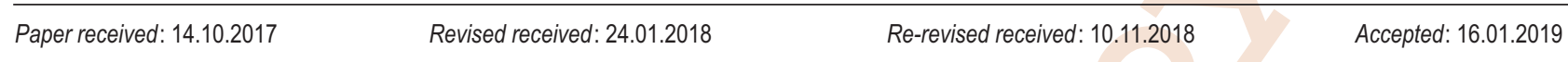

\section{Authors Info \\ R.A. Santos ${ }^{1}$, N.J. Sau', M.T. Certucha', F.J. Almendáriz², A.O. Monge ${ }^{2}$, I.J. Zepeda ${ }^{3}$ and L.J. Hernández ${ }^{1 *}$ \\ ${ }^{1}$ Centro de Investigaciones Biológicas del Noroeste SC, Hermosillo CP 83106, México \\ ${ }^{2}$ División de Ingeniería, Departamento de Ingeniería Química y Metalurgia, Universidad de Sonora, Hermosillo CP 83000 , México \\ ${ }^{3}$ Coordinación General de Infraestructura, Desarrollo Urbano y Ecología, Instituto Municipal de Ecología, Hermosillo CP 83270, México \\ *Corresponding Author Email : jhlopez04@cibnor.mx}

\section{Edited by \\ Dr. Juliana Righetto Moser}

Reviewed by Dr. Jacob Varghese Biboy Dr. Surya Prakash Dwivedi

\section{Abstract}

Aim : The microorganisms present in the air have great biological and economic importance because they can seriously affect living organisms. The aim of this work was to implement a real-time PCR technique as a rapid method for detecting Enterococcus faecalis in filters containing airborne particles, seeking to avoid the loss of time in bacterial culture on agar plates.

Methodology : Air filter samples were collected from four monitoring stations. Filter samples with $\mathrm{PM}_{10}$ and TSP particles were subjected to nucleic acid extraction and PCR for identification of $E$. faecalis.

Results : The PCR technique developed in this work showed high sensitivity and good specificity for detecting the presence of $E$. faecalis in airborne particles. The results of the microbiological analysis using traditional identification techniques confirmed the presence of $E$. faecalis in all sampling sites. Winter was the period with the highest percentage of positive samples.

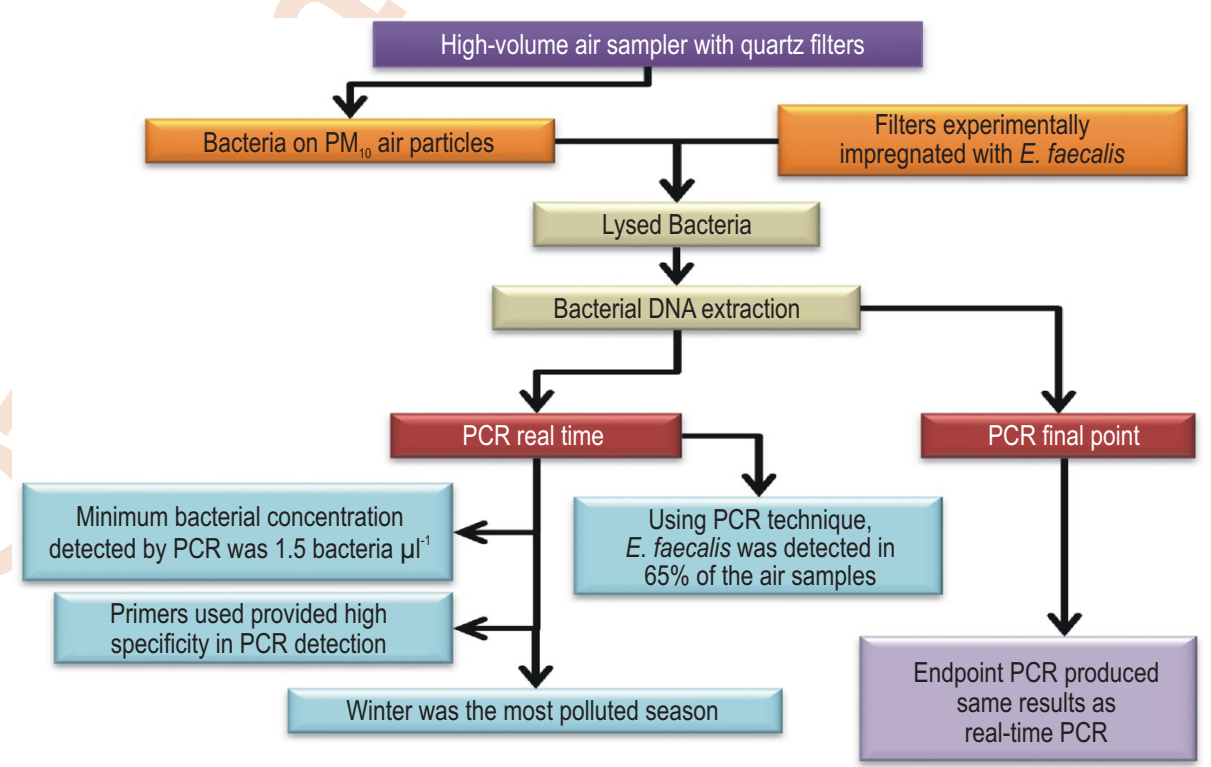

Interpretation : The results suggest that PCR technique can be used for rapid detection of $E$. faecalis in filters containing $\mathrm{PM}_{10}$ and TSP particles.

Key words: Air borne particles, Atmospheric, Enterococcus faecalis, Real-Time PCR

How to cite : Santos, R.A., N.J. Sau, M.T. Certucha, F.J. Almendáriz, A.O. Monge, I.J. Zepeda and L.J. Hernández: Rapid detection of bacteria, Enterococcus faecalis, in airborne particles of Hermosillo, Sonora, México. J. Environ. Biol., 40, 619-625 (2019). 


\section{Introduction}

Particulate air pollutants such as pollen, dust, carbon and metals such as cadmium and lead, salts, asbestos, sulfuric acid droplets, pesticides, dioxins and biological origin e.g., pollens, fungal spores, bacteria, viruses, etc. can cause serious health problems. Numerous studies on the effects of exposure to these contaminants have been associated with increased morbidity and mortality (Akhtar et al., 2014; Rojano et al., 2013; Tang et al., 2017). Inhalation of dust can reduce the function of lungs and induce development of allergic and immunotoxic symptoms (Awad, 2007). Even though the atmosphere has no native microbiota (Hurtado et al., 2014), the airborne microorganisms have a high biological and economic importance because they can cause diseases and disorders in living organisms (Núñez et al., 2016; Smets et al., 2016). Atmospheric particles have been subjected to microbiological studies in order to know infectious agents, allergens and fungal spores (Pan, 2015); these have been carried out by catching these particles in a broth or in solid agar for subsequent qualitative or quantitative analysis through biochemical and microscopic techniques (Hey et al., 2006). However, traditional methods for phenotypic identification based on bacteria cultures are laborious and may require several weeks to produce results (Biswas and Rolain, 2013); in contrast, molecular biology techniques can reduce the identification time and provide increasing accuracy, specificity and sensitivity (Espy et al., 2006; Saugar et al., 2015).

PCR is the most important technique in molecular biology (Garibyan and Avashia, 2013); it has simplified many laboratory procedures, allowing researchers to make significant progress in various fields such as biotechnology, ecology, evolution, conservation biology, archeology, pathology and forensic medicine among others (Cornejo et al., 2014). PCR is specific, simple and fast. Real-time PCR has been widely used for studying microbial aerosols in recent years due to high sensitivity and speed detection in quantitative and qualitative analysis of DNA and RNA(Hou et al., 2016; Li et al., 2013; Satoh et al., 2016). Enterococcus faecalis is a Gram-positive commensal anaerobic bacterium that inhabits the gastrointestinal tract of humans and some warm-blooded animals (Boehm and Sassoubre, 2014; Castillo et al., 2013). Like other species of the genus Enterococcus, E. faecalis can cause a wide variety of infections in humans, especially in hospitalized patients (Guzman et al., 2016) with a weak immune system.

These bacteria are considered indicators of fecal contamination (Boehm and Sassoubre, 2014), and its presence in food indicates poor hygiene or faulty storage conditions (Okeke Kingsley et al., 2014). The study of bacteria Enterococcus in the environment is important because these bacteria have the ability to acquire resistance to almost all antibiotics, and high distribution in environment increases the risk of transmission and bacteremia (Tedim et al., 2015). Some strains of Enterococcus spp. have physiological properties that facilitate their phenotypic characterization using conventional biochemical methods, however, in some cases the phenotypic similarity of strains makes it difficult to identify them. This problem can be avoided through the use of molecular methods based on nucleic acids that allow a more rapid identification of microorganism of genus Enterococcus. These methods include genetic tests, conventional PCR amplification, DNA-DNA hybridization, DNARNA hybridization and protein analysis; these are all an effective alternative for use of serological and biochemical characterization for the identification of Enterococcus spp. (Sepulveda et al., 2002; Siller-Ruiz et al., 2017).

The aim of this work was to implement a real-time PCR for molecular detection of $E$. faecalis in filters containing atmospheric particles captured by high volume samplers. The presence of this bacteria can be considered as a marker of fecal contamination associated with airborne particles in Hermosillo, Sonora.

\section{Materials and Methods}

Sample collection: Samples were collected at four different sampling stations; South station: COBACH High School, Central station: Dirección de Inspección y Vigilancia; North station: Universidad Estatal de Sonora (UES) and Northwest station: CBTIS 206 High School, during winter, spring and summer. Samples analyzed were collected $6^{\text {th }}$ day from each sampling station following the NOM protocol (SSA, 1993; 1994). PM particles were collected using a high-volume sampler with quartz filters (Whatman); TSP particles were collected using a TSP highvolume sampler (TE-5000) with fiberglass filters. The size of the filters was $20.3 \times 25.4 \mathrm{~cm}$. In the case of $\mathrm{PM}_{10}$ particles, the flow of air sampled was 1.02 to $1.24 \mathrm{~m} \mathrm{~min}^{-1}$; for TSP, the flow was 1.1 to 1.7 $\mathrm{m}^{3} \mathrm{~min}^{-1}$ for 24 consecutive hours both.

Bacteriological analysis: The samples used for analysis were obtained from $\mathrm{PM}_{10}$ and TSP filters. The unit sample area was $28.27 \mathrm{~mm}^{2}$. Bacteria were isolated on blood and chocolate agar after a previous enrichment in Brain Heart Infusion broth for $24 \mathrm{hrs}$ at $37^{\circ} \mathrm{C}$. The colonies were selected based on their morphology and Gram technique was used to define the cell morphology. Bacteria in the form of Gram-positive cocci were analyzed with catalase test to differentiate the Micrococcaceae and Streptococcacea families. Finally, catalase-negative bacteria that grew in selective medium Kenner Fecal were identified as Enterococcus faecalis by biochemical tests as mentioned in Bergey's Manual (Breed et al., 1957).

DNA extraction: DNA was extracted using affinity silica following the protocol described in the Gene Clean kit. DNA concentration was measured using a NanoDrop 2000 (Thermo Scientific) and stored at $-20^{\circ} \mathrm{C}$ until further use. The following alternative assay method for DNA extraction was also performed: the filters were placed into micro tubes with $500 \mu \mathrm{l}$ of nuclease-free water and heated at $95^{\circ} \mathrm{C}$ for $10 \mathrm{~min}$, followed by cooling at $-20^{\circ} \mathrm{C}$ for $5 \mathrm{~min}$. The sample was then centrifuged at $10,000 \mathrm{xg}$ for $5 \mathrm{~min}$; the DNA suspended in the supernatant was taken and the concentration was measured as specified above. 
Polymerase Chain Reaction (PCR) was performed using a commercial master mix (SYBR green I, Bio-Rad) following manufacturer's instructions, using primers specific for acetylcoenzyme A acetyltransferase gene: CAGCTTAAGTCAAGTAAGTGCCG (yiqLFw) and GAATATCCCTTCTGCTTGTGCT (yiqLRv). A real time thermocycler (Light Cycler 480) was used for PCR amplification under the following conditions: one cycle of $10 \mathrm{~min}$ at $94^{\circ} \mathrm{C}, 40$ cycles of $30 \mathrm{sec}$ at $94^{\circ} \mathrm{C}$, one cycle of $30 \mathrm{sec}$ at $60^{\circ} \mathrm{C}$, and one cycle of $30 \mathrm{sec}$ at $72^{\circ} \mathrm{C}$, with a final extension at $72^{\circ} \mathrm{C}$ for $5 \mathrm{~min}$. The PCR fragments were analyzed by melt curve analysis. APCR of final point was also performed for comparison with qPCR using the same run conditions.

The results were analyzed by melt curve analysis, adding $5 \mu \mathrm{l}$ of SYBR green I to the final reaction. For extracting $E$. faecalis DNA from sampling filters, the recovery efficiency of bacterial DNA from filters were compared with the efficiency of extraction using a pure culture of $E$. faecalis. For this, the concentration of bacteria was adjusted to $1.5 \times 10^{8}$ cells $\mathrm{ml}^{-1}$, the sampling filters were then impregnated with $15 \mu$ l of culture $\left(2.25 \times 10^{6}\right.$ bacteria), incubated at room temperature during $1 \mathrm{hr}$ and DNA was extracted for $\mathrm{qPCR}$ analysis.

Detection limit test: The detection limit was evaluated using $1 \mathrm{ml}$ of pure $E$. faecalis culture adjusted to $1.5 \times 10^{8}$ bacteria $\mathrm{ml}^{-1}$. Serial dilutions were performed from $1.5 \times 10^{8}$ to $1.5 \times 10^{5}$ bacteria $\mathrm{ml}^{-1}(1.5$ $x 10^{5}$ to 1.5 bacteria $\left.\mu l^{-1}\right)$. DNA in each dilution was extracted according to the method described above and PCR test was performed using the primers yiqLRv and yiqLFw.

\section{Results and Discussion}

The results of microbiological analysis, using traditional bacterial culture techniques (biochemical tests), revealed the presence of $E$. faecalis, all locations and sampling periods, in the Sonora state of Mexico country, with a high prevalence in the center station. Extraction of DNA using the Gene Clean method was suitable for PCR testing. An alternative method for DNA recovery by thermal shock was analyzed and compared with the Gene Clean method. The analysis showed that DNA extraction by both methods produced good quality DNA for PCR analysis. A
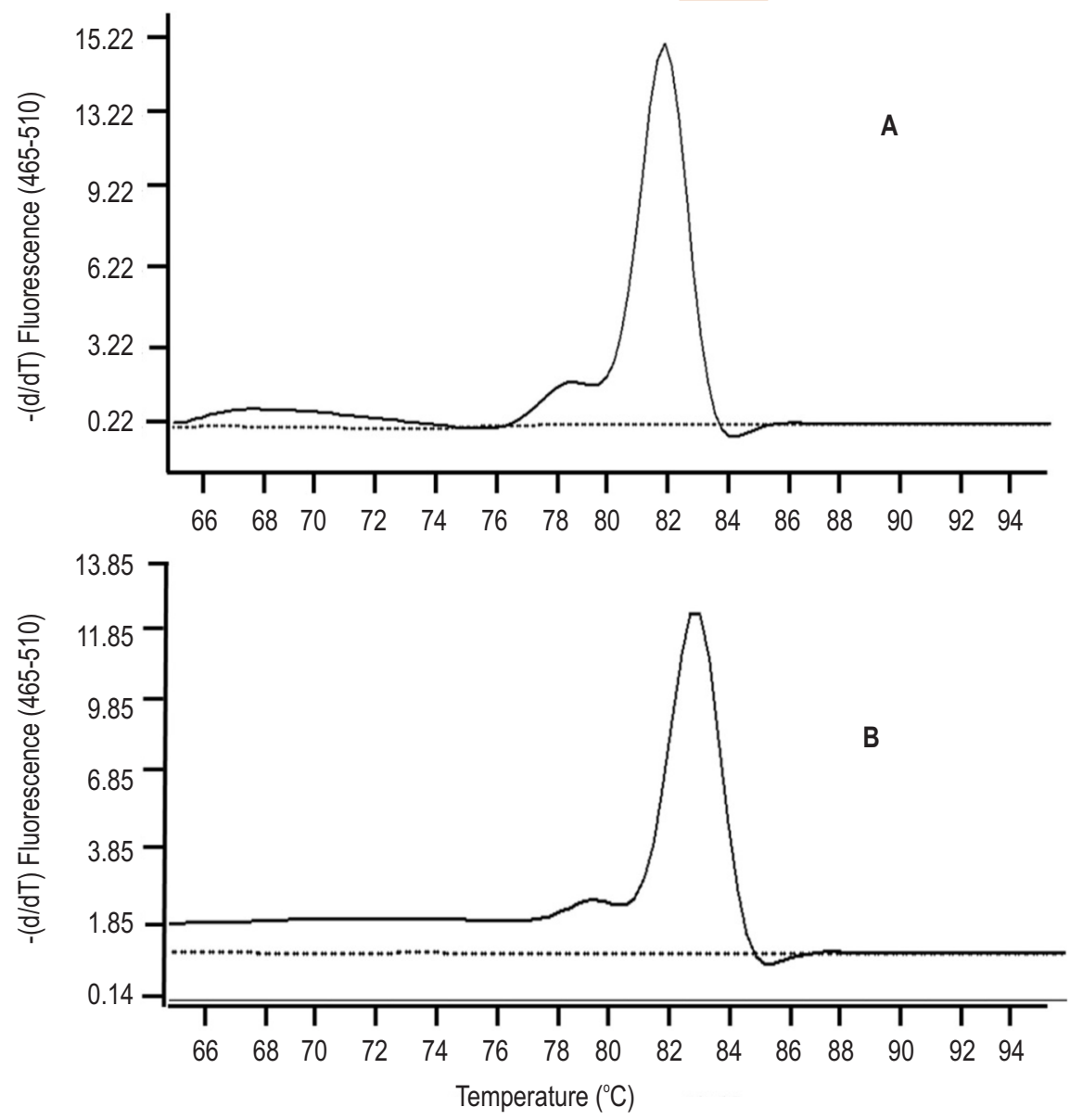

Fig. 1: Melting analysis of PCR products with DNA recuperated from filters impregnated with $E$. faecalis $\left(2.25 \times 10^{6}\right.$ bacteria $)$, using final point thermocycler (A) and real time thermocycler (B). 
total of 288 samples were analyzed; the concentration values

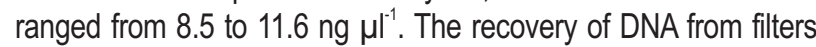
impregnated with pure culture of $E$. faecalis showed good efficiency (data not shown).

The recommended annealing temperature for primers used for molecular detection of $E$. faecalis is $52^{\circ} \mathrm{C}$ (Ruiz et al., 2006). Fixing of temperatures for annealing procedure in order to improve the specificity of test was evaluated. No difference were noted in the results when $52^{\circ} \mathrm{C}$ to $62^{\circ} \mathrm{C}$ temperature was applied. Therefore, all PCR tests were performed using an annealing temperature of $52^{\circ} \mathrm{C}$. PCR analysis was performed using primers specific for acetyl-coenzyme A acetyltransferase gene, named yiqLRv and yiqLFw (Ruiz et al., 2006). There was no difference in the results of samples analyzed by $q P C R$ or end point PCR (Fig. 1).

The $\mathrm{qPCR}$ reaction was performed using different volumes of DNA ( 1 to $3 \mu \mathrm{l})$; a $3 \mu$ l volume of DNA gave best results with no interferences in qPCR reaction. In this study, $3 \mu$ of sample were used for each $\mathrm{QPCR}$ reaction. The detection limit was evaluated using different dilutions of pure culture of $E$. faecalis. The results are shown in Fig. 2. The lowest bacterial concentration detected by PCR was 1500 bacteria $\mathrm{ml}^{-1}$. The specificity of qPCR for $E$. faecalis was evaluated using DNA extracted from other bacterial cultures, including Staphylococcus aureus, Escherichia coli (ATCC: 25922), Salmonella sp. Enterobacter aerogenes and Pseudomona aeruginosa. All DNA samples of bacteria different to $E$. faecalis showed negative qPCR (Fig. 3). Based on the results described above, a qPCR assay was designed using SYBR green I and a melt curve test was conducted to detect $E$. faecalis in air filter samples from Hermosillo, Sonora México. This assay included was DNA by thermal shock at following PCR conditions: $94^{\circ} \mathrm{C}$ for $5 \mathrm{~min} ; 40$ cycles at $94^{\circ} \mathrm{C}$ for $30 \mathrm{sec}, 52^{\circ} \mathrm{C}$ for $30 \mathrm{sec}, 72^{\circ} \mathrm{C}$ for $30 \mathrm{sec}$ and a final extension at $72^{\circ} \mathrm{C}$ for $7 \mathrm{~min}$. Forty-eight filter samples from Hermosillo City, containing PM10 air particles, were analyzed using the qPCR technique; the results showed that $E$. faecalis was present in all the locations sampled and that winter was found to be the most contaminated season. The percentage of samples that showed positive PCR for E. faecalis was: $43.8 \%$ in spring, $62.5 \%$ in summer and $87.5 \%$ in winter (Fig. 4). Using traditional bacteriology techniques, it was possible to detect the presence of bacteria such as E. faecalis (Santos et al., 2014).

Although recent molecular biology techniques have revolutionized clinical diagnosis, providing higher sensitivity and specificity (Sheerin et al., 2017), increasing the speed of diagnosis. Till date there are no reports on the use of these techniques, combined with high volume samplers, detect for pathogens in air samples on fiberglass filters containing $\mathrm{PM}_{10}$ and TSP particles. The present study implemented a technique for extracting nucleic acids in order to detect $E$. faecalis using $\mathrm{qPCR}$. The results showed that the extraction of nucleic acid using Gene Clean produced adequate amount of DNA of high purity.

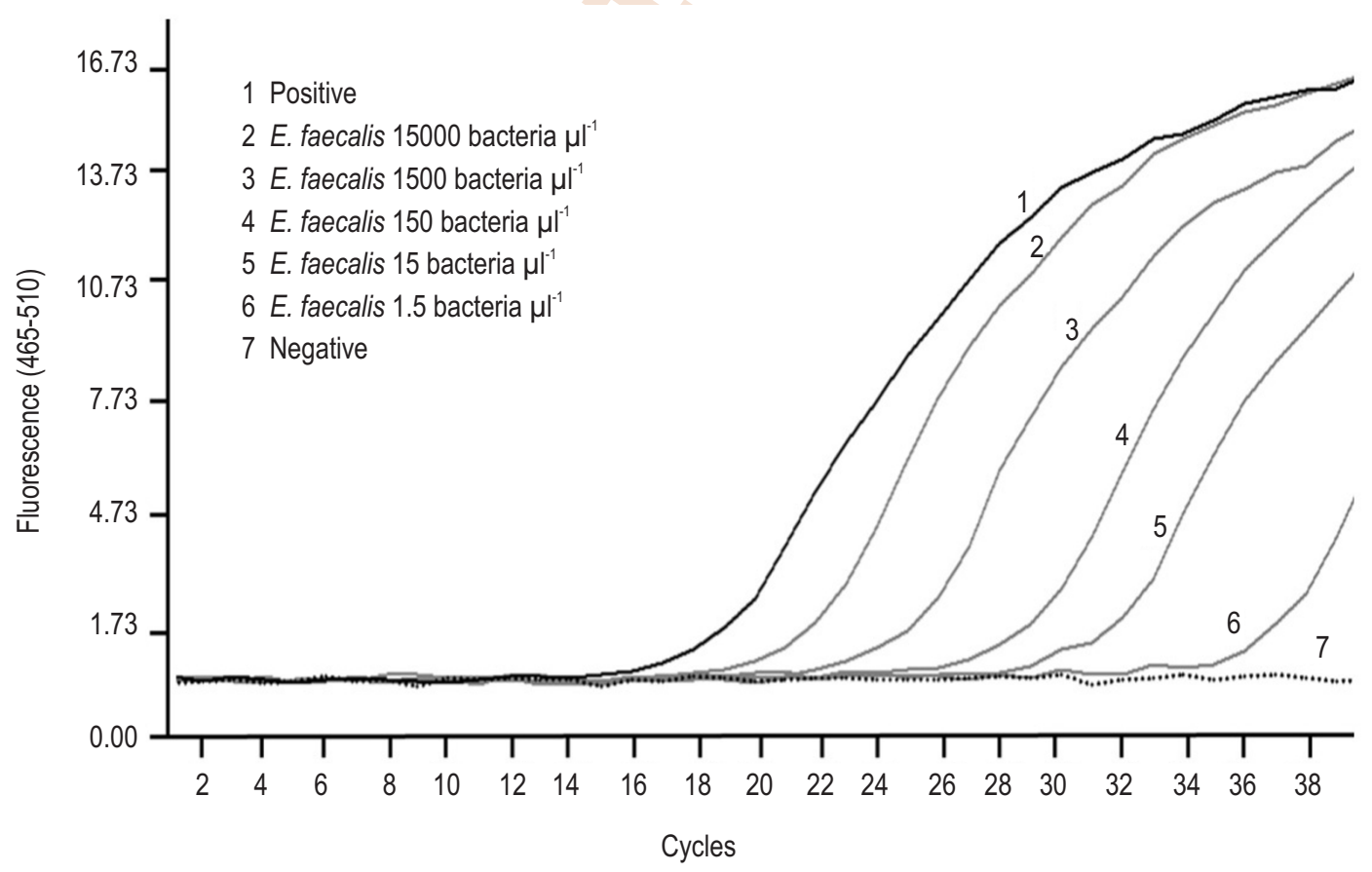

Fig. 2: Detection sensitivity for $E$. faecalis PCR. The minimum concentration detected was 1.5 bacteria $\mu l^{-1}$. 


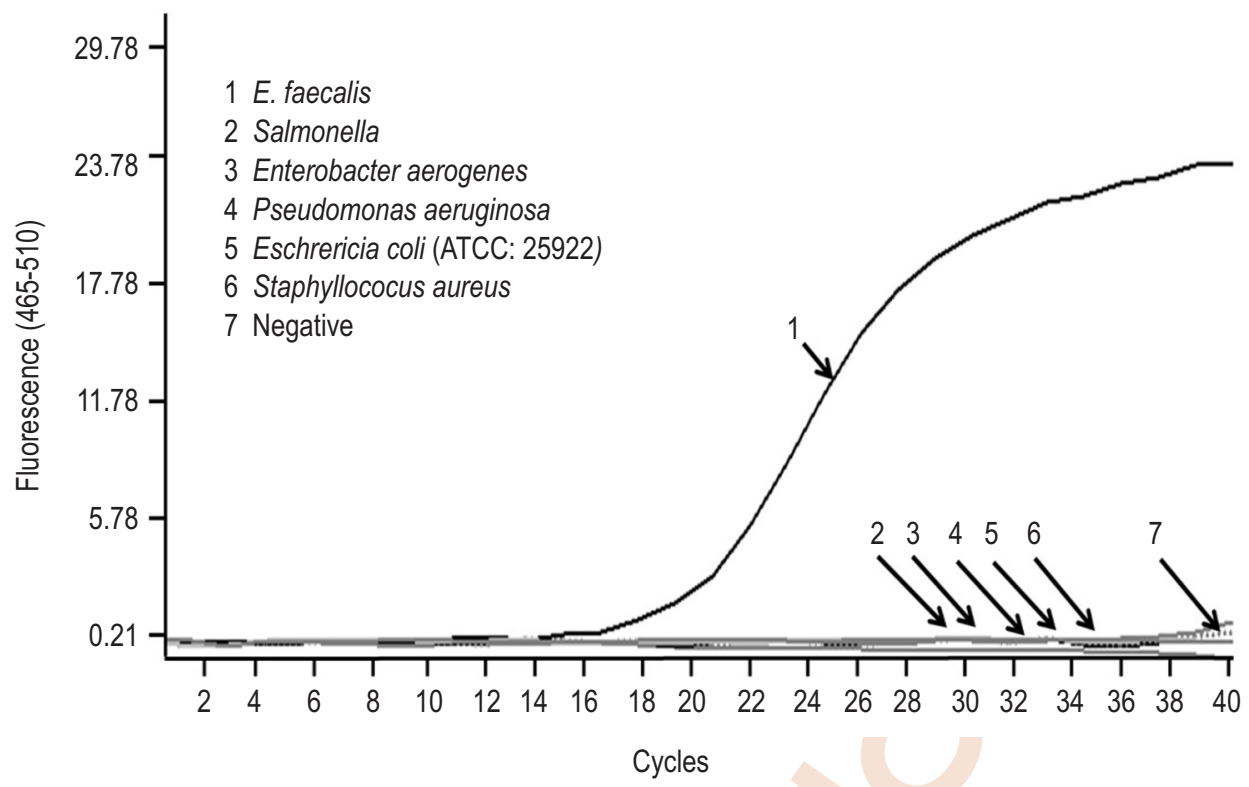

Fig. 3: Specificity probe for E. faecalis PCR. No amplification was recorded using DNA from Salmonella, Enterobacter aerogenes, Pseudomonas aeruginosa, Escherichia coli (ATCC: 25922) or Staphyllococcus aureus.

However, thermal shock is a cheaper and easier technique for extraction of bacterial DNA, yielding high concentrations of DNA of high purity like Gene Clean. Thus, this method can be used for the analysis of filters with atmospheric particles. The method designed for this study confirmed the presence of $E$. faecalis in air filter samples from the city of Hermosillo; Enterococcus faecalis has been previously reported in bacterial culture by Santos et al. (2014). The sensitivity of qPCR was 1500 bacteria $\mathrm{ml}^{-1}$, i.e., 3.5 bacterial cells could be detected in each qPCR test. Furthermore, the combination of primers used in this study yielded high

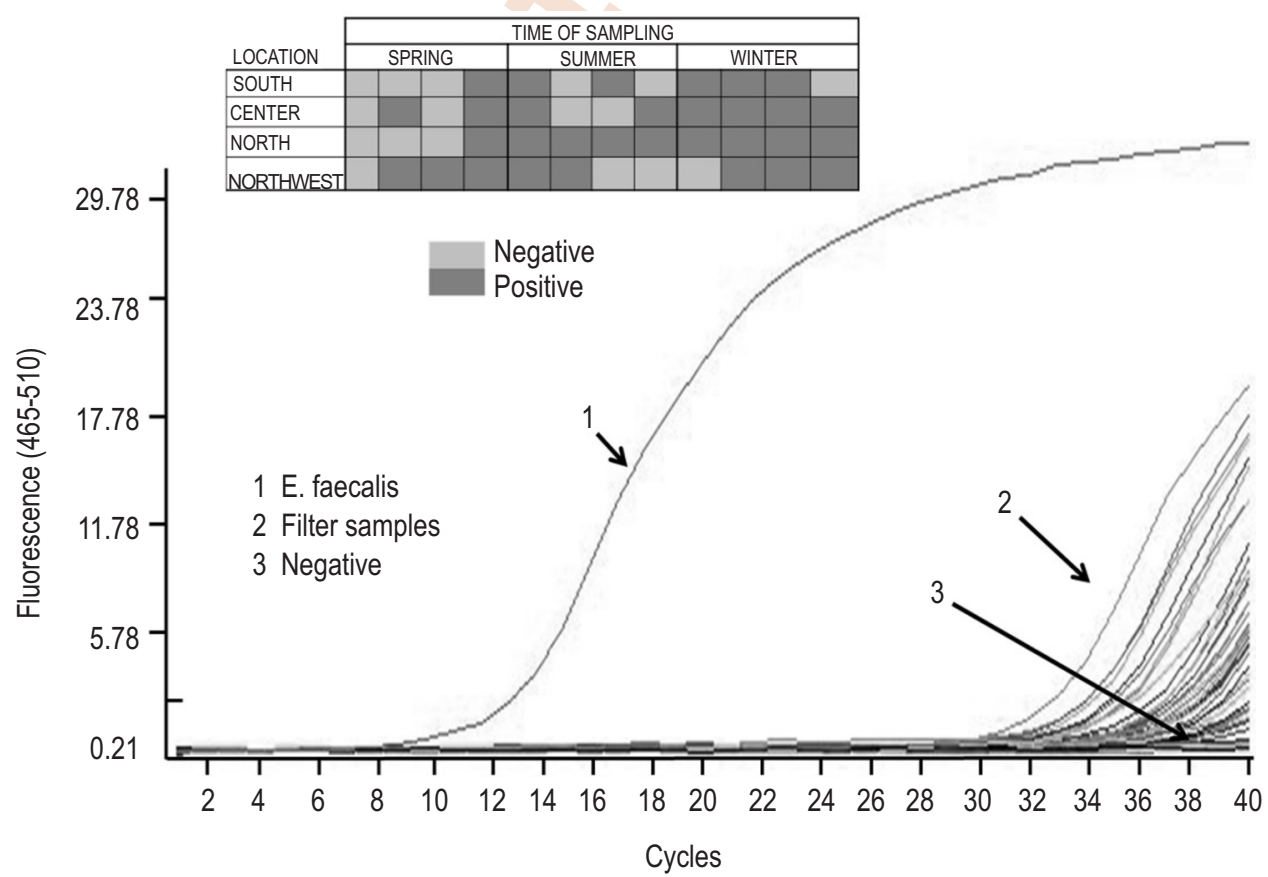

Fig. 4: PCR analysis of $E$. faecalis in air filtered samples collected from Hermosillo city in Sonora México. 
specificity; only samples with $E$. faecalis were detected, without cross-reactions with other bacteria. The presence of $E$. faecalis has been used as indicator of fecal contamination (Visnuvinayagam et al., 2017); its presence in food indicates poor hygiene practices. The presence of enterococci in the environment is important because this bacteria has the ability to acquire resistance to almost all antibiotics in use (Goldstein et al., 2014). In a previous study, Santos et al. (2014) observed that $E$. faecalis isolated from air filter samples from city of Hermosillo was resistant to almost all antibiotics, except Due to toxicity level of Vancomycin, it is recommended only as an antibiotic of last resort.

The results of this study revealed that the highest concentration of contaminants occurred in the center area of the city. Considering that downtown Hermosillo is the zone where most street-food is sold in the city, the risk of infection with $E$. faecalis for the local population may be very high. The presence of this bacterium in water has been reported to pose health risk (Alipour et al., 2014). The presence of Enterococci is considered as a marker of fecal contamination of natural sources of water (Boehm and Sassoubre, 2014; Harwood et al., 2014; Lleo del Mar et al., 2005). Compared with coliform bacteria, Enterococci have some advantages as indicator of safe hygienic practices; for example, they are more resistant to unfavorable natural conditions (Wheeler et al., 2002). Enterococciare associated with health risks to swimmers (Maraccini et al., 2012). Wade et al. (2010) reported a strong relationship between Enterococci and illness among swimmers in coastal waters.

This is the first report on $E$. faecalis detected by real time PCR in air filter samples. The ability to detect the presence of $E$. faecalis in air can be useful for public health institutions in countries prone to high incidence of bacterial infection. The qPCR technique developed in this work can be used to detect $E$. faecalis in drinking water, food, residual waters, pools, etc. The sensitivity and specificity of qPCR can be useful in epidemiological research.

\section{Acknowledgments}

We appreciate the valuable assistance provided by the Instituto Municipal de Ecología of Hermosillo city for allowing us to use the particle sampler equipment, as well as, Centro de Investigaciones Biológicas del Noroeste SC for all the facilities provided in their laboratories in Hermosillo Campus.

\section{References}

Akhtar, U.S., N. Rastogi, R.D. McWhinney, B. Urch, C.W. Chow, G.J. Evans and J.A. Scott: The combined effects of physico-chemical properties of size-fractionated ambient particulate matter on in vitro toxicity in human A549 lung epithelial cells. Toxicol. Reports, 1,145-156 (2014).

Alipour, M., R. Hajiesmaili, M. Talebjannat and Y. Yahyapour: Identification and antimicrobial resistance of Enterococcus spp. isolated from the river and coastal waters in Northern Iran. The Scie. World J., 2014, 287458 (2014).
Awad, A.H.A.: Airborne dust, bacteria, actinomycetes and fungi at a flourmill. Aerobiologia, 23, 59 (2007).

Biswas, S. and J.M. Rolain: Use of MALDI-TOF mass spectrometry for identification of bacteria that are difficult to culture. J. Microbiol. Meth., 92, 14-24 (2013).

Boehm, A.B. and L.M. Sassoubre: Enterococci as an indicators of environmental fecal contamination. In: Enterococci: From commensals to leading causes of drug resistant infection [Internet] (Eds.: M.S. Gilmore, D.B. Clewell, Y.lke and N. Shankar). Boston: Massachusetts Eye and Ear Infirmary (2014).

Breed, R.S.M., E. Smith and R. Nathan: Bergey's Manual of Determinative Bacteriology. $7^{\text {th }}$ Edn., The Williams \& Wilkins Company, Baltimore USA (1957).

Castillo, R.G., H.M. Mazari, D.L.S. Ponce, F.R.I. Amieva, J.R.A. Agis, J. Huebner and V.Y. López: Comparison of Enterococcus faecium and Enterococcus faecalis strains isolated from water and clinical samples: Antimicrobial susceptibility and genetic relationships. PIOS ONE, 8, e59491 (2013).

Cornejo, R., D. Serrato, B. Aguilar and M. Munive: Herramientas moleculares aplicadas en ecología: Aspectos teóricos y prácticos. Molecular tools applied in ecology: Theoretical and practical aspects. SEMARNAT, INECC, UAM-I, (2014).

Espy, M., J. Uhl, L. Sloan, S. Buckwalter, M. Jones, E. Vetter, J. Yao, N. Wengenack, J. Rosenblatt and F. Cockerill: Real-time PCR in clinical microbiology: Applications for routine laboratory testing. Clin. Microbiol. Rev.,19, 165-256 (2006).

Garibyan, L. and N. Avashia: Research techniques made simple: Polymerase chain reaction (PCR). The J. Invest. Dermatol., 133 e6 (2013).

Goldstein, R.E.R., S.A. Micallef, S.G. Gibbs, A. George, E. Claye, A. Sapkota, S.W. Joseph and A.R. Sapkota: Detection of vancomycin-resistant enterococci (VRE) at four US wastewater treatment plants that provide effluent for reuse. Sci. Total Environ., 466, 404-411 (2014)

Guzman, P.A.M., V.S. Willem, M.R. Rogers, T.M. Coque, F. Baquero, J. Corander and R.J. Willems: Global emergence and dissemination of enterococci as nosocomial pathogens: Attack of the clones? Front. Microbiol., 7, 788 (2016).

Harwood, V.J., C. Staley, B.D. Badgley, K. Borges and A. Korajkic Microbial source tracking markers for detection of fecal contamination in environmental waters: Relationships between pathogens and human health outcomes. FEMS Microbiol. Rev., 38, 1-40 (2014).

Hey, R.A., G. Mainelis and L. White: Development and calibration of realtime PCR for quantification of airborne microorganisms in air samples. Atmos. Environ., 40, 7924-7939 (2006).

Hou, L., X. Zhang, Y. Li, S. Chen, H. Qu, J. Yu, L. Zhang and Z. Fan: Rapid screening of recombinant plasmids by direct colony quantitative Real-Time PCR. Adv. Biosci. Biotechnol., 7, 428 (2016).

Hurtado, L., G. Rodríguez, J. López, J. Castillo, L. Molina, M. Zavala and P.J. Quintana: Characterization of atmospheric bioaerosols at 9 sites in Tijuana, Mexico. Atmos. Environ., 96, 430-436 (2014).

Li, S., Y. Li, L. Zhang and Z. Miao: Application of Real-Time Polymerase Chain Reaction (PCR) in detection of microbial aerosols. Environ. Forensics, 14, 16-19 (2013).

Lleo del Mar, M., B. Bonato, D. Benedetti and P. Canepari: Survival of enterococcal species in aquatic environments. FEMS Microbiol. Ecol., 54, 189-196 (2005)

Maraccini, P.A., D.M. Ferguson and A.B. Boehm: Diurnal variation in Enterococcus species composition in polluted ocean water and a potential role for the enterococcal carotenoid in protection against photoinactivation. Appl. Environ. Microb., 78, 305-310 (2012).

Núñez, A., G. Amo de Paz, A. Rastrojo, A.M. García, A. Alcamí, A.M. 
Gutierrez-Bustillo and D.A. Moreno: Monitoring of the airborne biological particles in outdoor atmosphere. Part 1: Importance, variability and ratios. Int. Microbiol., 19, 1-13 (2016).

Okeke Kingsley, S., O. Abdullahi Isa and A. Makun Hussaini: Microbiological quality of dairy cattle products. British Microbiol. Res. J., 4, 1409-1417 (2014).

Pan, Y.L.: Detection and characterization of biological and other organiccarbon aerosol particles in atmosphere using fluorescence. J. Quantit. Spectrosc. Radia. Trans., 150, 12-35(2015).

Rojano, R.E., L.C. Angulo and G. Restrepo: Niveles de Partículas Suspendidas Totales (PST), $\mathrm{PM}_{10}$ y $\mathrm{PM}_{2.5}$ y su relación en lugares públicos de la Ciudad Riohacha, Caribe Colombiano. Tota Suspended Particle (TSP), $\mathrm{Pm}_{10}$ and $\mathrm{PM}_{2.5}$ levels and its relation in public places of the Riohacha city, Colombian Caribbean. Información Tecnológica, 24, 37-46 (2013).

Ruiz, G.P., M.J. Bonten, D.A. Robinson, J. Top, S.R. Nallapareddy, C. Torres, T.M. Coque, R. Cantón, F. Baquero and B.E. Murray: Multilocus sequence typing scheme for Enterococcus faecalis reveals hospital-adapted genetic complexes in a background of high rates of recombination. J. Clin. Microbiol., 44, 2220-2228 (2006).

Santos, R.A., A.N.J. Sau, B.M.T. Certucha, T.F.J. Almendáriz, A.O Monge, L.J. Hernández and I.J. Zepeda: Microbiological identification of atmospheric particles in Hermosillo, Sonora, México. J. Environ. Prot., 5, 376-386 (2014).

Satoh, H., D. Imai, S. Sato, K. Furuhama and R. Harasawa: Molecular detection of Mycoplasma haemomuris subspecies using dnaKtargeted Real-Time PCR with SYBR Green I and melting curve analysis. Mol. Cell Probe., 30, 291-293 (2016).

Saugar, J.M., F.J. Merino, P. Martín-Rabadán, P. Fernández-Soto, S. Ortega, T. Gárate and E. Rodríguez: Application of Real-Time PCR for the detection of Strongyloides spp. in clinical samples in a reference center in Spain. Acta Trop.,142, 20-25 (2015).

Sepúlveda, M., H. Bello, M. Ruiz, J. Hormazábal, M. Domínguez, G. González, S. Mella and R. Zemelman: Metodología clásica y molecular en la identificación de especies de Enterococcus spp. Classical and molecular methodology in the identification of species of Enterococcus spp. Rev. Med. Chile., 130, 45-49 (2002).

Sheering, B.B., K. Ramprasad, M. A. Azeem and M. R. Bharath Screening and identification of oleaginous moulds for lipid production. J. Environ. Biol., 38, 697-701 (2017).

Siller-Ruiz, M., S. Hernández-Egido, F. Sánchez-Juanes, J.M. González-Buitrago and J.L. Muñoz-Bellido: Fast methods of fungal and bacterial identification. MALDI-TOF mass spectrometry, chromogenic media. Enferm. Infec. Microbiol. Clin., $35,303-313(2017)$
Smets, W., S. Moretti, S. Denys and S. Lebeer: Airborne bacteria in the atmosphere: Presence, purpose and potential. Atmos. Environ., 139, 214-221 (2016).

SSA: Norma Oficial Mexicana NOM-024-SSA1-1993, Salud ambiental Criterio para evaluar la calidad del aire ambiente con respecto a partículas suspendidas totales (PST). Valor permisible para la concentración de partículas suspendidas totales (PST) en el aire ambiente como medida de protección a la salud de la población Official Mexican Standard NOM-024-SSA1-1993, Environmental Health. Criterion to evaluate the quality of the ambient air with respect to total suspended particles (TSP). Permissible value for the concentration of total suspended particles (TSP) in ambient air as a measure of protection to the health of the population. Salud Ambiental (1993).

SSA: Norma Oficial Mexicana NOM-025-SSA1-1993. Salud ambiental. Criterio para evaluar la calidad del aire ambiente, con respecto a las partículas menores de 10 micras $\left(\mathrm{PM}_{10}\right)$. Valor permisible para la concentración de partículas menores de 10 micras $\left(\mathrm{PM}_{10}\right)$ en el aire ambiente, como medida de protección a la salud de la población. Official Mexican Standard NOM-025-SSA1-1993. Environmental health: Criterion to evaluate the quality of ambient air, with respect to particulates less than 10 microns $\left(\mathrm{PM}_{10}\right)$. Allowable value for the concentration of particles smaller than 10 microns $\left(\mathrm{PM}_{10}\right)$ in ambient air as a protective measure the health of the population. Salud Ambiental, 23, (1994).

Tang, G., P. Zhao, Y. Wang, W. Gao, M. Cheng, J. Xin, X. Li and Y. Wang: Mortality and air pollution in Beijing: The long-term relationship. Atmos. Environ., 150, 238-243 (2017).

Tedim, A.P., P. Ruiz-Garbajosa, J. Corander, C.M. Rodríguez, R. Cantón, R.J. Willems, F. Baquero and T.M. Coque: Population biology of intestinal Enterococcus isolates from hospitalized and nonhospitalized individuals in different age groups. Appl. Environ. Microb., 81, 1820-1831 (2015).

Visnuvinayagam, S., L. N. Murthy, P. Viji and G. K. Sivaraman: Study on retail fish markets: Possible occurance and transmission of emergeing pathogen from faecal indicators. J. Environ. Biol., 38, 465-470 (2017).

Wade, T.J., E. Sams, K.P. Brenner, R. Haugland, E. Chern, M. Beach, L. Wymer, C.C. Rankin, D. Love and Q. Li: Rapidly measured indicators of recreational water quality and swimming-associated illness at marine beaches: A prospective cohort study. Environ. Hlth., 9,66 (2010).

Wheeler, A.L., P.G. Hartel, D.G. Godfrey, J.L. Hill and W.I. Segars: Potential of as a human fecal indicator for microbial source tracking. J. Environ. Qual., 31, 1286-1293 (2002). 